\title{
Preliminary observations on the benthic marine algae of the Gorringe seabank (northeast Atlantic Ocean)
}

\author{
Ian Tittley • Nuno Miguel da Silva Vaz Álvaro • \\ Ana Isabel de Melo Azevedo Neto
}

Received: 3 September 2013/Revised: 18 March 2014/ Accepted: 20 March 2014/Published online: 9 April 2014

(c) Springer-Verlag Berlin Heidelberg and AWI 2014

\begin{abstract}
Examination of marine samples collected in 2006 from the Gettysburg and Ormonde seamounts on the Gorringe seabank southwest of Portugal has revealed 29 benthic Chlorophyta, Phaeophyceae (Ochrophyta), and Rhodophyta that were identified provisionally to genus and to species. Combining lists for the present and a previous expedition brings the total of algae thus far recorded to 48 . The brown alga Zonaria tournefourtii and the red alga Cryptopleura ramosa were the most abundant species in the present collections. The kelp Laminaria ochroleuca was present only in the Gettysburg samples while Saccorhiza polyschides was observed only on the Ormonde seamount. Comparisons with the benthic marine algae recorded on seamounts in the mid-Atlantic Azores archipelago show features in common, notably kelp forests of $L$. ochroleuca at depths below $30 \mathrm{~m}$ and $Z$. tournefortii dominance in shallower waters.
\end{abstract}

Communicated by F. Weinberger.

I. Tittley $(\bowtie)$

Department of Life Sciences, Natural History Museum, London SW7 5BD, UK

e-mail: it@nhm.ac.uk

N. M. da Silva Vaz Álvaro

Centro de estudos do Clima, Metereologia e Mudanças Globais

da Univeridade dos Azores, Ponta Delgada, Portugal

N. M. da Silva Vaz Álvaro - A. I. de Melo Azevedo Neto CIRN and Grupo de Biologia Marinha, Departamento Biologia, Universidade dos Açores, 9501-801 Ponta Delgada, Azores, Portugal

N. M. da Silva Vaz Álvaro - A. I. de Melo Azevedo Neto Centro Interdisciplinar de Investigação Marinha e Ambiental (CIIMAR), Rua dos Bragas 289, 4050-123 Porto, Portugal
Keywords Benthic algae $\cdot$ Gorringe seabank $\cdot$ Northeast Atlantic $\cdot$ Seamounts $\cdot$ Rocky subtidal

\section{Introduction}

Seamounts are undersea mountains over that occur in all ocean basins but few of which have been sampled for their marine biota (Hall-Spencer et al. 2011). They rise steeply from the abyssal plain and may ascend to shallow depths within the photic zone and create suitable habitat for benthic algae. It has been suggested that seamounts may function as stepping stones for the transoceanic dispersal of benthic species and may also host endemic species. However, a recent review using mainly faunistic data (Rowden et al. 2010) drew attention to gaps in our knowledge of seamount biodiversity and ecology and questioned hitherto-held views on seamounts as unique and fragile environments, and hot spots of biodiversity and endemicity.

The Gorringe seabank (Fig. 1), part of the Horseshoe seamounts range and Paleo Madeira (Madeiran volcanic province, Fernández-Palacios et al. 2011), contains two prominent peaks, the Ormonde and Gettysburg seamounts (Anon 2005). The Gorringe seabank and Paleo Madeiran seamounts are on the African tectonic plate separated from Europe by the Azores-Gibraltar fracture zone. The Gorringe seabank is over $180 \mathrm{~km}$ long (Anon 2005) and lies southwest of Cape St Vincent, Portugal with the Gettysburg seamount approximately $240 \mathrm{~km}$ offshore and the Ormonde $200 \mathrm{~km}$ offshore. The seabank rises from $5,000 \mathrm{~m}$ depth to the photic zone with peaks $<50 \mathrm{~m}$ below sea level. Its surface is composed of recent conglomerates and lava flows with some areas of exposed carbonate rock (Anon 2005). A previous investigation on the Gorringe seabank that employed SCUBA diving to record its marine 
Fig. 1 Location of the Gorringe seabank and Gettysburg and Ormonde seamounts

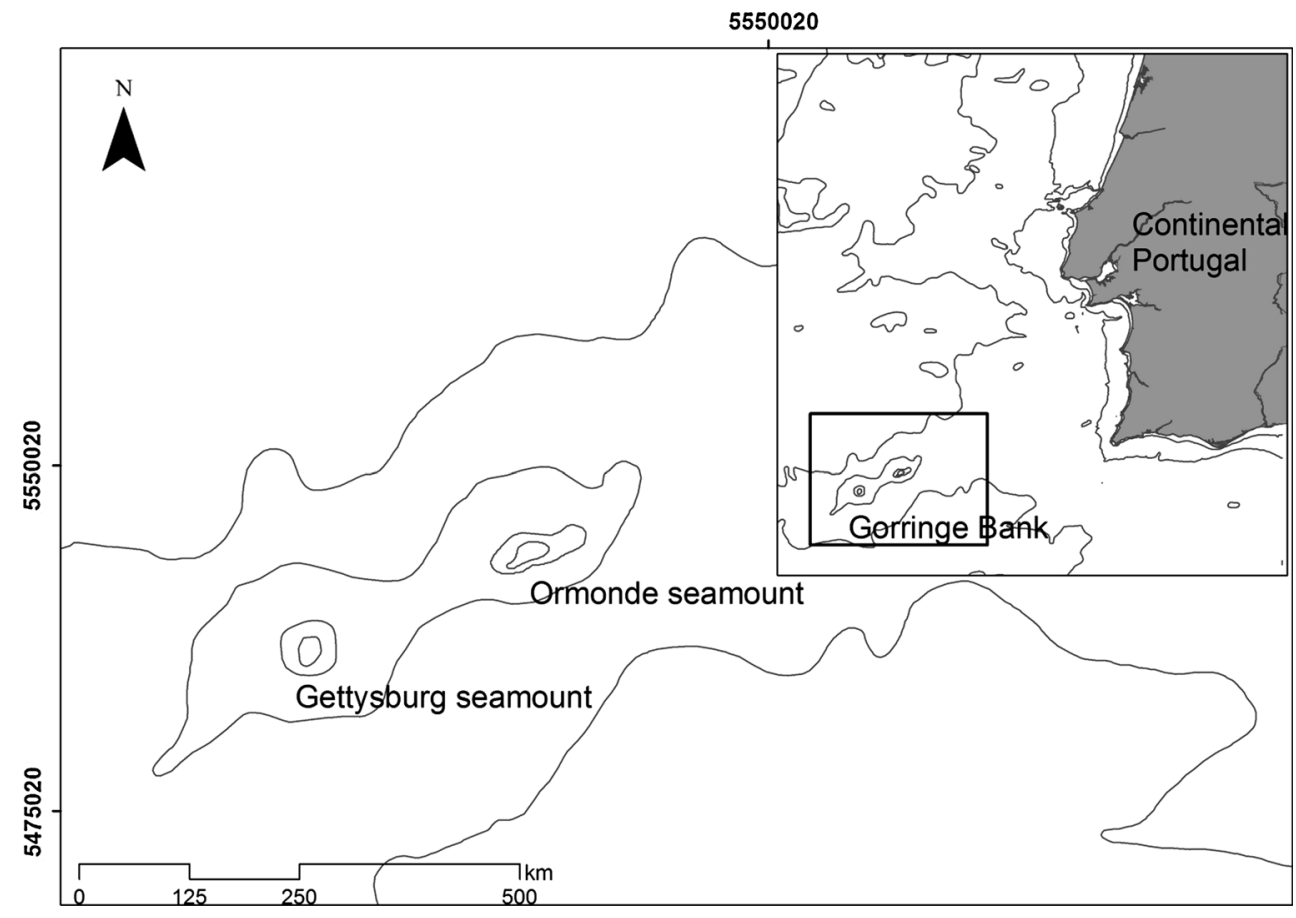

life recorded 26 benthic marine algae (Anon 2005). There have been no investigations on the benthic marine algal flora of other seamounts in the region; the nearest comparable studies have been undertaken on seamounts in the mid-Atlantic Azores archipelago (latitude $37^{\circ}-40^{\circ} \mathrm{N}$; 1,100-1,600 km from mainland Europe) where similar surface and deep sea temperatures and water clarity prevail; algae have been recorded from the Dom João de Castro seabank, the Princess Alice seabank, the Formigas islets (2-3 $\mathrm{m}$ above sea level) and nearby Dollarbarat reef (Cardigos et al. 2005; Neto 1994; Santos et al. 2001).

The field study undertaken in 2006 gathered further biological and ecological data to support conservation designation (Anon 2013). This paper reports the benthic algae obtained during investigations of the Gettysburg and Ormonde seamounts.

\section{Materials and methods}

Qualitative collections of benthic algae were obtained during the Lusoexpedição 2006 (Lusófona University expedition) supported by the Portuguese navy. The Gettysburg and Ormonde seamounts are in clear oceanic water with visibility to $30 \mathrm{~m}$ depth; the aphotic zone is at $>200 \mathrm{~m}$ depth (de Alteriis et al. 2003). Surface sea temperatures range annually from 15 to $24{ }^{\circ} \mathrm{C}\left(22-23{ }^{\circ} \mathrm{C}\right.$ at the time of investigation) with a thermocline at depth $50 \mathrm{~m}$ below which temperature dropped by $4{ }^{\circ} \mathrm{C}$ (pers. comm. Coriolis Data Centre); the deep sea temperature profile for $37^{\circ} \mathrm{N}$ $11^{\circ} \mathrm{W}$ (near the Gorringe seabank, Peliz et al. 2005) shows little variation in the top $100 \mathrm{~m}$ of the water column when temperature was $17{ }^{\circ} \mathrm{C}$ in May 1998. Tidal amplitude does not exceed $2.2 \mathrm{~m}$ (de Alteriis et al. 2003) with a small surface current to $15 \mathrm{~m}$ depth at the diving sites.

SCUBA diving surveys for algae, part of a wider biological survey, were undertaken in July 2006 on six occasions on the Gettysburg $\left(36^{\circ} 31^{\prime} \mathrm{N}, 11^{\circ} 34^{\prime} \mathrm{W}\right)$ and two occasions on the Ormonde $\left(36^{\circ} 02^{\prime} \mathrm{N}, 11^{\circ} 09^{\prime} \mathrm{W}\right)$ seamounts at depths of, respectively, 35 and $39.6 \mathrm{~m}$. Material collected was preserved in neutralized $4 \%$ formaldehyde seawater and brought back to the laboratory for identification. Algae were identified to species with the aid of keys and floras, principally Afonso-Carillo and Sansón (2000); Lawson and John (1987); Maggs and Hommersand (1993); Taylor (1967); some were identified provisionally, others only to genus while notably the crustose Corallinaceae remained largely undetermined. Algal nomenclature follows Guiry and Guiry (2013). Specimens have been deposited in the herbarium Guy Telles Palhinha of the Department of Biology of the University of the Azores, Ponta Delgada (AZB).

\section{Results}

The present investigation revealed 29 algae (3 Chlorophyta, 7 Phaeophyceae, 19 Rhodophyta) that were identified provisionally to genus and in many cases to species. The total of algae listed for the Gorringe seabank including 
Table 1 Marine algae recorded from the Gorringe seabank and their biogeographical occurrence

\begin{tabular}{|c|c|c|c|c|c|c|c|c|c|c|c|c|c|c|}
\hline Species & $\begin{array}{l}\mathrm{Gb} \\
06\end{array}$ & $\begin{array}{l}\text { Or } \\
06\end{array}$ & $\begin{array}{ll}\mathrm{Gr} & \mathrm{sb} \\
\mathrm{pr} & \end{array}$ & $a b$ & $\mathrm{Pt}$ & $\mathrm{Az}$ & $\begin{array}{l}\mathrm{Az} \\
\mathrm{sm}\end{array}$ & $\mathrm{Md}$ & $\mathrm{Cn}$ & Med & $\begin{array}{l}\text { Atl } \\
\text { en }\end{array}$ & $\begin{array}{l}\text { Atl } \\
\text { est }\end{array}$ & $\begin{array}{l}\text { Atl } \\
\text { wst }\end{array}$ & Ind \\
\hline
\end{tabular}

Rhodophyta

Acrochaetium sp.

Acrosorium ciliolatum (Harvey) Kylin

Aglaothamnion cf. sepositum (Gunnerus)

Maggs and Hommersand

Aglaothamnion sp.

Botryocladia cf. chiajeana (Meneghini) Kylin

Callithamnion tetragonum (Withering) S.F.Gray

Callophyllis laciniata (Hudson) Kützing

Cryptopleura ramosa (Hudson) L.Newton

Cryptonemia seminervis (C.Agardh)

J.Agardh

Dasya cf. caraibica Børgesen

Erythrotrichia carnea (Dillwyn) J.Agardh

Gracilaria cf. multipartita (Clemente)

Harvey

Halymenia floresii (Clemente) C.Agardh

Halymenia sp.

Hypoglossum hypoglossoides (Stackhouse) F.S.Collins and Hervey

Irvinea $\mathrm{cf}$. ardreana (J.Brodie and Guiry) Guiry

Kallymenia cf. reniformis (Turner) J.Agardh

Kallymenia cf. requienii (J.Agardh)

J.Agardh

Laurencia cf. obtusa (Hudson)

J.V.Lamouroux

Lithophyllum incrustans Philippi

Lithophyllum cf. stictaeforme (Areschoug)

Hauck

Meiodiscus spetsbergensis (Kjellman)

G.W.Saunders and McLachlan

Mesophyllum alternans (Foslie) Cabioch and M.L.Mendoza

Mesophyllum sp.

Nitophyllum punctatum (Stackhouse)

Greville

Palmaria palmata (Linnaeus) Weber and Mohr

Peyssonnelia cf. inamoena Pilger

Plocamium cartilagineum sensu lato cf.

Saunders and Lemkuhl (2005)

Pyropia leucosticta (Thuret) Neefus and J.Brodie

Rhodophyllis divaricata (Stackhouse) Papenfuss

\begin{tabular}{|c|c|c|c|c|c|c|c|c|c|c|c|c|c|c|c|}
\hline+ & + & 0 & ep & $\mathrm{r}$ & - & - & - & - & - & - & - & - & - & - & - \\
\hline 0 & + & 0 & ep & $\mathrm{r}$ & + & + & + & + & + & + & + & + & + & + & + \\
\hline 0 & 0 & + & $\mathrm{u}$ & $\mathrm{u}$ & 0 & 0 & 0 & 0 & 0 & + & + & 0 & 0 & 0 & 0 \\
\hline 0 & + & - & ep & $\mathrm{r}$ & - & - & - & - & - & - & - & - & - & - & - \\
\hline+ & + & 0 & el & o & 0 & + & 0 & + & + & + & 0 & + & 0 & + & 0 \\
\hline 0 & + & 0 & $\mathrm{u}$ & $\mathrm{r}$ & + & + & 0 & + & + & + & + & + & 0 & 0 & 0 \\
\hline 0 & 0 & + & $\mathrm{u}$ & $\mathrm{u}$ & + & 0 & 0 & 0 & 0 & + & + & + & 0 & 0 & + \\
\hline+ & + & + & $\begin{array}{l}\mathrm{ep} / \\
\mathrm{el}\end{array}$ & $\mathrm{a}$ & + & + & + & + & + & + & + & + & + & 0 & + \\
\hline+ & 0 & 0 & el & $\mathrm{r}$ & + & + & 0 & 0 & + & + & + & + & + & + & + \\
\hline+ & + & 0 & el & $\mathrm{f}$ & 0 & 0 & 0 & 0 & + & + & + & + & + & + & + \\
\hline+ & + & 0 & ep & o & + & + & 0 & 0 & + & + & + & + & + & + & + \\
\hline+ & 0 & 0 & el & $\mathrm{f} / \mathrm{o}$ & + & + & 0 & 0 & 0 & 0 & + & + & 0 & 0 & 0 \\
\hline 0 & 0 & + & $\mathrm{u}$ & $\mathrm{u}$ & + & 0 & 0 & 0 & 0 & + & 0 & + & + & + & + \\
\hline+ & 0 & 0 & $\mathrm{u}$ & $\mathrm{r}$ & - & - & - & - & - & - & - & - & - & - & - \\
\hline 0 & + & 0 & $\mathrm{u}$ & o & + & + & 0 & + & + & + & + & + & + & + & + \\
\hline 0 & 0 & + & $\mathrm{u}$ & $\mathrm{u}$ & + & 0 & 0 & 0 & 0 & 0 & $+\mathrm{p}$ & 0 & 0 & 0 & 0 \\
\hline 0 & 0 & + & el & $\mathrm{u}$ & + & + & 0 & + & + & + & + & + & 0 & + & + \\
\hline 0 & + & + & el & $\mathrm{r}$ & 0 & 0 & 0 & 0 & + & + & 0 & 0 & 0 & 0 & 0 \\
\hline 0 & 0 & + & $\mathrm{u}$ & $\mathrm{u}$ & + & + & 0 & + & + & + & + & + & + & + & + \\
\hline 0 & 0 & + & el & $\mathrm{u}$ & + & + & + & 0 & + & + & + & + & + & + & + \\
\hline 0 & 0 & + & $\mathrm{u}$ & $\mathrm{u}$ & 0 & 0 & 0 & + & + & + & 0 & + & + & 0 & + \\
\hline+ & 0 & 0 & $\mathrm{ez}$ & $\mathrm{r}$ & 0 & 0 & 0 & 0 & 0 & + & 0 & + & 0 & 0 & + \\
\hline 0 & 0 & + & $\mathrm{u}$ & $\mathrm{u}$ & + & + & 0 & 0 & + & + & + & 0 & 0 & 0 & 0 \\
\hline+ & 0 & 0 & $\begin{array}{l}\mathrm{el} / \\
\mathrm{ep}\end{array}$ & o & - & - & - & - & - & - & - & - & - & - & - \\
\hline 0 & + & 0 & ep & $\mathrm{r}$ & + & + & 0 & + & + & + & + & + & + & + & + \\
\hline 0 & 0 & + & $\mathrm{u}$ & $\mathrm{u}$ & + & + & 0 & 0 & 0 & 0 & + & 0 & 0 & + & + \\
\hline 0 & 0 & + & $\mathrm{u}$ & $\mathrm{u}$ & 0 & 0 & 0 & + & + & + & + & + & + & + & + \\
\hline+ & + & + & $\mathrm{u}$ & $\mathrm{u}$ & + & + & 0 & + & + & + & + & + & + & + & + \\
\hline 0 & 0 & + & $\mathrm{u}$ & $\mathrm{u}$ & + & + & 0 & + & + & + & + & $?$ & $?$ & + & + \\
\hline+ & + & + & $\begin{array}{l}\mathrm{ep} / \\
\mathrm{el}\end{array}$ & $\mathrm{a}$ & + & + & + & + & + & + & + & + & 0 & 0 & 0 \\
\hline 0 & 0 & + & $\mathrm{u}$ & $\mathrm{u}$ & 0 & 0 & 0 & 0 & 0 & + & 0 & 0 & 0 & 0 & 0 \\
\hline
\end{tabular}


Table 1 continued

\begin{tabular}{|c|c|c|c|c|c|c|c|c|c|c|c|c|c|c|c|c|}
\hline Species & $\begin{array}{l}\mathrm{Gb} \\
06\end{array}$ & $\begin{array}{l}\text { Or } \\
06\end{array}$ & $\begin{array}{l}\mathrm{Gr} \\
\mathrm{pr}\end{array}$ & $\mathrm{sb}$ & $\mathrm{ab}$ & $\mathrm{Pt}$ & $\mathrm{Az}$ & $\begin{array}{l}\mathrm{Az} \\
\mathrm{sm}\end{array}$ & $\mathrm{Md}$ & $\mathrm{Cn}$ & Med & $\begin{array}{l}\text { Atl } \\
\text { en }\end{array}$ & $\begin{array}{l}\text { Atl } \\
\text { est }\end{array}$ & $\begin{array}{l}\text { Atl } \\
\text { wst }\end{array}$ & Ind & $\mathrm{Pac}$ \\
\hline $\begin{array}{l}\text { Spermothamnion strictum (C.Agardh) } \\
\text { Ardissone }\end{array}$ & 0 & + & 0 & ep & $\mathrm{r}$ & 0 & 0 & 0 & 0 & 0 & + & + & 0 & 0 & 0 & 0 \\
\hline Titanoderma sp. & 0 & 0 & + & $\mathrm{u}$ & $\mathrm{u}$ & - & - & - & - & - & - & - & - & - & - & - \\
\hline \multicolumn{17}{|l|}{ Ochrophyta-Phaeophyceae } \\
\hline Arthrocladia villosa (Hudson) Duby & 0 & 0 & + & $\mathrm{u}$ & $\mathrm{u}$ & + & 0 & 0 & + & + & + & + & 0 & + & 0 & 0 \\
\hline $\begin{array}{l}\text { Desmarestia ligulata (Stackhouse) } \\
\text { J.V.Lamouroux }\end{array}$ & + & + & 0 & el & $\mathrm{c}$ & + & 0 & 0 & 0 & 0 & + & + & 0 & + & 0 & + \\
\hline $\begin{array}{l}\text { Dictyopteris polypodioides (A.P.De } \\
\text { Candolle) J.V.Lamouroux }\end{array}$ & 0 & 0 & + & $\mathrm{u}$ & $\mathrm{f}$ & + & + & + & + & + & + & + & + & + & + & + \\
\hline $\begin{array}{l}\text { Dictyota dichotoma (Hudson) } \\
\text { J.V.Lamouroux }\end{array}$ & 0 & 0 & + & el & $\mathrm{u}$ & + & + & + & + & + & + & + & + & + & + & + \\
\hline Ectocarpus siliculosus (Dillwyn) Lyngbye & 0 & + & 0 & $\mathrm{u}$ & $\mathrm{u}$ & + & + & 0 & + & + & + & + & + & + & + & + \\
\hline Halopteris filicina (Grateloup) Kützing & + & 0 & + & $\mathrm{u}$ & $\mathrm{u}$ & + & + & 0 & + & + & + & + & 0 & + & + & + \\
\hline Laminaria ochroleuca Bachelot de la Pylaie & + & 0 & + & el & $\mathrm{f}$ & + & + & + & 0 & + & + & + & $?$ & + & 0 & 0 \\
\hline $\begin{array}{l}\text { Lobophora variegata (J.V.Lamouroux) } \\
\text { Womersley ex E.C.Oliveira }\end{array}$ & + & 0 & 0 & el & o & 0 & 0 & + & + & + & + & 0 & + & + & + & + \\
\hline Saccorhiza polyschides (Light-foot) Batters & 0 & + & 0 & el & $\mathrm{f}$ & + & 0 & 0 & 0 & $0 \mathrm{~d}$ & + & 0 & 0 & 0 & 0 & 0 \\
\hline $\begin{array}{l}\text { Sporochnus pedunculatus (Hudson) } \\
\text { C.Agardh }\end{array}$ & 0 & 0 & + & el & $\mathrm{u}$ & + & + & 0 & + & + & + & + & 0 & + & + & + \\
\hline $\begin{array}{l}\text { Zonaria tournefortii (J.V.Lamouroux) } \\
\text { Montagne }\end{array}$ & + & + & + & el & a & + & + & + & + & + & + & $+\mathrm{p}$ & + & + & 0 & 0 \\
\hline \multicolumn{17}{|l|}{ Chlorophyta } \\
\hline Bryopsis hypnoides J.V.Lamouroux & 0 & + & 0 & $\mathrm{u}$ & $\mathrm{r}$ & + & + & 0 & + & + & + & + & 0 & + & + & + \\
\hline Valonia cf. aegagropila C.Agardh & 0 & 0 & + & el & $\mathrm{u}$ & 0 & 0 & 0 & 0 & $?$ & + & 0 & 0 & + & + & + \\
\hline Valonia macrophysa Kützing & 0 & + & 0 & el & o & 0 & + & 0 & + & + & + & 0 & 0 & + & + & + \\
\hline Valonia utricularis (Roth) C.Agardh & 0 & + & 0 & el & o & + & + & + & + & + & + & $+\mathrm{p}$ & + & + & + & + \\
\hline Total out of 42 algae identified to species & & & & & & 31 & 27 & 9 & 24 & 31 & 40 & 34 & 26 & 27 & 25 & 29 \\
\hline
\end{tabular}

$G b$ Gettysburg, Or Ormonde, $G r$ previous Gorringe list (Anon 2005), $s b$ substratum, $a b$ abundance, $P t$ Portugal, Az Azores, Az sm Azores seamounts, Md Madeira, Cn Canaries, Med Mediterranean Sea, Atl en eastern North Atlantic, Atl est eastern subtropical and tropical Atlantic, Atl wst western subtropical and tropical Atlantic, Ind Indian Ocean, Pac Pacific Ocean; + = present, $0=$ not recorded, $-=$ no information, $?=$ uncertain record, $\mathrm{a}=$ abundant, $\mathrm{cf} .=$ resembles, $\mathrm{d}=\mathrm{drift}, \mathrm{el}=$ epilithic, $\mathrm{ep}=$ epiphytic, $\mathrm{ez}=$ epizoic, $\mathrm{f}=$ frequent, $\mathrm{o}=\mathrm{occasional}$, $\mathrm{p}=$ Portugal only, $\mathrm{r}=$ rare, $\mathrm{u}=$ unknown

those from the previous expedition is 48 comprising 4 Chlorophyta, 11 Phaeophyceae, and 33 Rhodophyta. These are listed in Table 1 together with the substrata upon which they grew, their relative abundance in the samples, their occurrence in adjacent Portugal, and the Azores, Madeira and Canaries archipelagos, and more widely in the Atlantic and other oceans.

\section{Discussion}

This study has increased the total of benthic marine algae known for the Gorringe seabank from 26 to 48 of which five were determined to genus only. Most species in the present samples were Rhodophyta; there were only a few species of Phaeophyceae and Chlorophyta although in both collections, the foliose Zonaria tournefortii was dominant and served as a host substratum for epiphytic algae. The list presented here (Table 1) is provisional as some of the species included are problematic; examples include Bryopsis hypnoides (Brodie et al. 2007), Laurencia obtusa (Cassano et al. 2012), Lobophora variegata (Sun et al. 2012), and Plocamium cartilagineum (Saunders and Lemkuhl 2005). Of the 43 algae identified to species, 40 occur in the Mediterranean Sea while 33 occur in the Macaronesian archipelagos (Azores, Madeira, Canaries). Thirtyone species occur on the relatively nearby coast of Portugal, 34 species more widely in the eastern and western subtropical and tropical regions of the Atlantic Ocean other than the Macaronesian islands, and 33 in the temperate northeast Atlantic. Thirty species found on the Gorringe seabank occur globally widely in the Indian and Pacific Oceans (with the caveat that some may prove to encompass several entities, e.g., Lobophora, Sun et al. 2012). The 
major proportion of benthic algal species on the Gorringe seabank occur in the Mediterranean Sea and eastern and western subtropical and tropical Atlantic Ocean (Table 1), demonstrating a warm-water floristic affinity. Currently, no endemic algal species have been recorded for the Gettysburg and Ormond seamounts.

Differences were found in the collections from the two seamounts. Present only on the Gettysburg were Cryptonemia seminervis, Gracilaria cf. multipartita, Halymenia sp. Meiodiscus spetsbergensis, Measophyllum sp., Halopteris filicina, Laminaria ochroleuca and Lobophora variegata while on the Ormonde only were Acrosorium ciliolatum, Aglaothamnion sp., Hypoglossum hypoglossoides, Kallymenia $\mathrm{cf}$. requienii, Nitophyllum punctatum, Spermothamnion strictum, Ectocarpus siliculosus, Saccorhiza polyschides, Bryopsis hypnoides, Valonia macrophysa and V. utricularis. Reasons for the differing algal assemblages and the separate occurrence of the kelps L. ochroleuca and $S$. polyschides, respectively, on these seamounts are unclear, but may reflect a gradient of changing algal species assemblages as noted by O'Hara et al. (2010) in the southwest Atlantic Ocean.

Of the 27 benthic algae (1 Chlorophyta, 8 Phaeophyceae and 18 Rhodophyta) previously recorded on the Gorringe seabank (Anon 2005), five (Cryptopleura ramosa, Kallymenia reniformis, Plocamium cartilagineum, Rhodophyllis divaricata, Zonaria tournefortii) were confirmed in the 2006 survey. By contrast, 14 Rhpdophyta, 4 Phaeophyceae, and 1 Chlorophyta were recorded previously but not in 2006 (Table 1); reasons for these differences are also unclear but may be due to different approaches to sampling, rare or sporadic occurrence, and to differences in taxonomic interpretation.

The combined total of 48 algae on the Gorringe seabank is small compared with the more thoroughly researched adjacent flora of southern Iberia with over 500 species (Tittley 2003). The species-poor flora of the seabank reflects the very limited geographical and seasonal scope of the study, the absence of an intertidal flora, the limitations in investigating a permanently immersed isolated offshore site where the shallow sublittoral flora is missing and the deep-water assemblage below $40 \mathrm{~m}$ depth requires different methods of sampling and recording (see Littler et al. 1986; Vadas and Steneck 1988).

Studies on seamounts in the Azores archipelago have revealed 53 benthic algae of which 36 occurred on the Dom João de Castro seabank where rocky habitats at 25-45 m depth were dominated by a mosaic of Sargassum sp., Corallina sp., and Stypocaulon scoparium with at greater depths, as on the Gorringe seabank, Z. tournefortii as the dominant species (Cardigos et al. 2005). Twenty-two species have been recorded on the Formigas islets (Neto 1994) where Cystoseira sp. occurred at shallow depths and
L. ochroleuca (specimens in AZB) below $40 \mathrm{~m}$ depth; $L$. ochroleuca forests occur on the Gorringe seabank but Cystoseira has not been found there. Of 53 algae recorded on the Azores seamounts, only ten are currently known to occur on the Gorringe seabank. Zonaria tournefortii has been recorded on seamounts elsewhere in the tropical Atlantic Ocean (Littler et al. 1986) while L. ochroleuca has a more northern warm temperate distribution in the northeast Atlantic (Tittley 2003). The presence of foliose brown algae (L. variegata, Z. tournefortii) typical of the tropics and subtropics and kelps (L. ochroleuca, S. polyschides) more typical of temperate waters reflects the geographical position of the Gorringe seabank in a boundary area of the North Atlantic Ocean. However, Graham et al. (2007) predict the widespread occurrence of deep-water kelp habitats and forests in subtropical and tropical waters where, as on the Gorringe seabank and in the Azores, deep waters might have adequate sea temperatures and nutrient supply (cf. Coelho and Santos 2003 for the Gorringe seabank) to support kelp growth (see also Santelices 2007). On the Gorringe seabank, L. ochroleuca and $S$. polyschides were collected in the warmer waters above the thermocline at $50 \mathrm{~m}$ depth; the cooler waters at greater depths remain unexplored for algae. Graham et al. (2007) also discovered the temperate macroalga Desmarestia ligulata further south in the Pacific Ocean in deep waters around the Galápagos islands; these species were present in the 2006 samples from the Gettysburg and Ormonde seamounts.

\section{Conclusions}

Field studies confirm an extensive cover of benthic algae on the peaks of the submerged Gorringe seabank; its currently known flora of 48 benthic algae is small compared with mainland Portugal. The flora shows affinities with the warm-water floras of the Mediterranean Sea, southern Iberia, and the Macaronesian archipelagos. The geographically wide occurrence of most algal species on the Gorringe seabank suggests that its seamounts are not floristically isolated islands. Evidence for Gettysburg and Ormonde seamounts as hot spots of algal species richness is lacking despite the species richness of this geographical area but much more sampling remains to be done. These isolated sea mounts probably have served as stepping stones for algal dispersal in the region.

Acknowledgments This work was partly supported by CIRN (Centro de Investigação de Recursos Naturais, University of the Azores). It was funded by FEDER through the COMPETE Program and by FCT (Fundação para a Ciència e Tecnologia) under the multiannual fund (Pest-C/MAR/LA0015/2011). Nuno Vaz Álvaro was funded by Fundo Regional de Ciência dos Açores (M3.1.2/F/015/ 
2011). The authors wish to thank Mónica Albuquerque, Juliet Brodie, Gonçalo Calado, Linda Irvine, Miguel Souto, and Joana Xavier for their help in various ways.

\section{References}

Afonso Carillo J, Sansón M (2000) Algas, hongos y fanerógamas marinas de las Islas Canarias Clave analítica, 2nd edn. Universidad de La Laguna, La Laguna

Anon (2005) The seamounts of the Gorringe Bank. Oceana, Madrid. http://eu.oceana.org

Anon (2013) Portugal to nominate Gorringe Bank as new marine protected area. http://oceana.org/en/media-reports/press-releases/ portugal-to-nominate-gorringe-bank-as-new-marine-protected-area

Brodie J, Maggs CA, John DM (2007) Green seaweeds of Britain and Ireland. British Phycological Society, London

Cardigos F, Colaço A, Dando PR, Ávila SP, Sarradin PM, Tempera F, Conceição P, Pascoal A, Serrão Santos R (2005) Shallow water hydrothermal vent field fluids and communities of the D. João de Castro seamount (Azores). Chem Geol 224:153-168

Cassano V, Metti Y, Millar AJK, Gil-Rodríguez C, Sentiés A, DiazLarrea J, Oliveira MC, Fujii MT (2012) Redefining the taxonomic status of Laurencia dendroidea (Ceramiales, Rhodophyta) from Brazil and the Canary Islands. Eur J Phycol 47:67-81

Coelho H, Santos R (2003) Enhanced primary production over seamounts: a numerical study. Thalassas 19:144-145

de Alteriis G, Passaro S, Tonielli R (2003) New, high resolution swath bathymetry of Gettysburg and Ormonde seamounts (Gorringe Bank, eastern Atlantic) and first geological results. Mar Geophys Res 24:223-244

Fernández-Palacios JM, de Nascimento L, Rüdiger O, Delgado JD, Garcia-del-Rey E, Arévalo JR, Whittaker RJ (2011) A reconstruction of Paleo-Macaronesia, with particular reference to the long-term biogeography of the Atlantic island laurel forests. J Biogeogr 38:226-246

Graham MH, Kinlan BP, Druehl LD, Garske LE, Banks S (2007) Deep-water kelp refugia as potential hotspots of tropical marine diversity and productivity. Proc Nat Acad Sci 104:16576-16580

Guiry MD, Guiry GM (2013) Algaebase. World-wide electronic publication, National University of Ireland, Galway. http://www. algaebase.org

Hall-Spencer J, Clark M, Consalvey M, Rowden A, Stocks K, Schlacher T (2011) A celebration of life on seamounts. Porcup Mar Nat Hist Soc Newsl 30:54-56
Lawson GW, John DM (1987) The marine algae and coastal environment of tropical West Africa (second edition). Beih Nova Hedwig 93:vi+1-415

Littler MM, Littler DS, Blair SM, Norris JN (1986) Deep-water plant communities from an uncharted seamount off San Salvador Island, Bahamas: distribution, abundance, and primary productivity. Deep Sea Res 33:881-892

Maggs CA, Hommersand MH (1993) Seaweeds of the British Isles Rhodophyta volume 1 part 3A Ceramiales. HMSO, London

Neto AI (1994) Checklist of the benthic marine macroalgae of the Azores. Arquipél Life Mar Sci 12A:15-34

O’Hara TD, Consalvey M, Lavrado HP, Stocks KJ (2010) Environmental predictors and turnover of biota along a seamount chain. Mar Ecol 31(Suppl. 1):84-94

Peliz A, Dunert J, Santos AMP, Oliveira PB, Le Cann B (2005) Winter upper ocean circulation in the western Iberian Basinfronts, eddies and poleward flows: an overview. Deep Sea Res 52:621-646

Rowden AA, Dower JF, Consalvey M, Clark MR (2010) Paradigms in seamount ecology: fact, fiction and future. Mar Ecol 31(Suppl. 1):226-241

Santelices B (2007) The discovery of kelp forests in deep water habitats of tropical regions. Proc Nat Acad Sci 104:19163-19164

Santos RS, Tempera F, Cardigos F, Salgado M (2001) Habitat mapping of Sites of Conservation Importance (SCIs) around the Azores islands for management purposes. Arquipél Life Mar Sci 21A:75-80

Saunders GW, Lemkuhl KV (2005) Molecular divergence and morphological diversity among four cryptic species of Plocamium (Plocamiales, Florideophyceae) in northern Europe. Eur J Phycol 40:293-312

Sun Z, Hanyuda T, Lim P-E, Tanaka J, Gurgel CFD, Kawai H (2012) Taxonomic revision of the genus Lobophora (Dictyotales, Phaeophyceae) based on morphological evidence and analyses $r b c \mathrm{~L}$ and $c o x 3$ gene sequences. Phycologia 51:500-512

Taylor WR (1967) Marine algae of the eastern tropical and subtropical coasts of the Americas. University of Michigan Press, Ann Arbor

Tittley I (2003) Seaweed diversity in the North Atlantic Ocean. Arquipél Life Mar Sci 19A:13-32

Vadas RL, Steneck RS (1988) Zonation of deep water benthic algae in the Gulf of Maine. J Phycol 24:338-346 